\author{
MAŁGORZATA GIEŁDA \\ ORCID: 0000-0003-1510-2758 \\ Uniwersytet Wrocławski \\ Instytut Nauk Administracyjnych \\ Zakład Ustroju Administracji Publicznej
}

\title{
OTOCZENIE ADMINISTRACJI PUBLICZNEJ - WYBRANE ZAGADNIENIA
}

\begin{abstract}
Abstrakt: Między organizacją a jej otoczeniem zawsze istnieją sprzężenia zwrotne. W odniesieniu do administracji publicznej będą one dotyczyły przede wszystkim spraw, w zakresie których prawo zezwala lub nakazuje jej działać. Publikacja zwraca uwagę na rolę zasobów ludzkich w administracji publicznej i jej otoczeniu, przedstawia także odmienność oraz specyfikę otoczenia administracji publicznej względem innych organizacji i związane z tym skutki. Otoczenie administracji publicznej zostało także ukazane w kontekście współczesnej kategorii socjologicznej — prekariatu.
\end{abstract}

Słowa kluczowe: otoczenie organizacji, administracja publiczna, organizacja, potrzeba indywidualna, potrzeba grupowa, prawo, prekarność

\section{WPROWADZENIE}

Pojęcie otoczenia organizacji jest $\mathrm{w}$ nauce bardzo dobrze opisane. Zagadnieniem tym zajmują się przede wszystkim podręczniki i monografie z zakresu nauk o organizacji i zarządzaniu, jest ono także przedmiotem innych nauk (nauka o administracji, socjologia, ekonomia, marketing, prawo). Pojęcie otoczenia jest więc interdyscyplinarne i nie ma uniwersalnej definicji.

Większość badań i analiz otoczenia organizacji odnosi się ogólnie do organizacji lub organizacji biznesowych (komercyjnych). Jednak specyfikę administracji publicznej określa także jej otoczenie, które często kieruje się odmiennymi od ogólnych regułami i wzorcami.

Przedmiotem tego opracowania jest otoczenie administracji publicznej. Rozważania oparte zostały na podstawach teoretycznych w przedmiotowym zakresie, czyli na ogólnym pojęciu otoczenia organizacji w literaturze przedmiotu, jego cechach i rodzajach. W odniesieniu do tego tła zostaną przedstawione i poddane analizie wybrane zagadnienia związane $\mathrm{z}$ charakterystyką otoczenia administracji publicznej, a także uwypuklone jego cechy szczególne. 


\section{POJĘCIE OTOCZENIA ORGANIZACJI}

Traktując to pojęcie najogólniej, można stwierdzić, że otoczeniem jest wszystko to, „co znajduje się poza organizacją i może na nią oddziaływać”1. Takie ujęcie otoczenia jest bardzo elastyczne i pojemne, odnosi się do wielu kategorii czynników: ekonomicznych, społecznych, prawnych, technicznych, socjologicznych, naturalnych. Szeroki zasięg tej definicji podkreśla użycie słowa „może”, które zwraca uwagę na to, że właściwie każdy czynnik znajdujący się na zewnątrz organizacji jest potencjalnym elementem mogącym budować jej otoczenie.

Bogusław Kaczmarek i Czesław Sikorski przedstawiają otoczenie jako podstawową determinantę strategii organizacji (przedsiębiorstwa) i również w sposób ogólny formułują jego definicję. Ich zdaniem „otoczenie to suma czynników, które wpływają lub mogą wpływać na jakikolwiek aspekt funkcjonowania przedsiębiorstwa, na jego cele, wielkość, strukturę, wyniki i metody działania"2. Wpływ otoczenia na działalność i powodzenie organizacji podkreśla także Barbara Łopusiewicz, konstruując to pojęcie w odniesieniu do pozyskiwania przez organizację informacji z zewnątrz. Tak ujęte otoczenie stanowi ,źródło wiedzy o konkurentach, trendach pojawiających się w obszarze działalności organizacji, klientach i dostawcach, rynkach oraz źródło wszelkich innych informacji istotnych dla organizacji”3.

Robert Dilts zwraca z kolei uwagę przede wszystkim na tak zwane konkretne otoczenie. Jednak określając je, także wychodzi od bardziej ogólnego sformułowania:

Otoczenie jest zewnętrznym kontekstem, w którym zachodzą nasze zachowania oraz interakcje. „Otoczenie” jest wszystkim, co postrzegamy „na zewnątrz” nas. Konkretne „otoczenie” składa się z takich czynników otaczających jednostkę czy grupę, jak: typ pomieszczenia, warunki pogodowe, pożywienie, poziom hałasu itd. ${ }^{4}$

Autor odróżnia więc już na poziomie definicji otoczenie ogólne organizacji od otoczenia konkretnego i odnosi do jednostki lub grupy przede wszystkim warunki, w jakich działają na rzecz organizacji.

Przez pryzmat konkretnych czynników otoczenie organizacji definiuje także Zbigniew Martyniak:

Otoczenie to całokształt czynników fizycznych (temperatura, oświetlenie, wilgotność powietrza), ekonomicznych (poziom cen, możliwości zbytu) i socjologicznych (uzdolnienia i poziom umysłowy personelu, stosunki międzyludzkie), które łącznie tworzą środowisko systemu organi-

${ }^{1}$ L.F. Korzeniowski, Menedżment. Podstawy zarządzania, Kraków 2010, s. 400.

2 B. Kaczmarek, C. Sikorski, Podstawy zarzadzania. Zachowania organizacyjne, Łódź 1998, s. $61-62$.

3 Zarzadzanie wiedza w systemach informacyjnych, red. B. Łopusiewicz, Wrocław 2004 (parafraza, s. 23).

${ }^{4}$ R. Dilts, Od przewodnika do inspiratora, Warszawa 2006, s. 3. 
zacyjnego. Wyposażenie obejmuje ogół środków technicznych (maszyny, narzędzia) stosowanych $\mathrm{w}$ procesie. Wreszcie ostatnią cechę charakterystyczną stanowią zasoby ludzkie, przy pomocy których w określonym otoczeniu, stosując wyposażenie, w ustalonym procesie przekształca się wejście w wyjście i osiąga pożądany $\operatorname{cel}^{5}$.

W ten sposób stworzył zamknięty katalog czynników budujących otoczenie i uwzględnił w nim: czynniki fizyczne, ekonomiczne, socjologiczne, wyposażenie organizacji (środki techniczne) oraz zasoby ludzkie.

Otoczenie organizacji może być także definiowane w kontekście kontroli — w tej perspektywie

obejmuje wszystkie czynniki, które mają wpływ na organizację, nad którymi nie ma kontroli lub które można kontrolować w znikomym stopniu. Do tych czynników należą: klienci; uwarunkowania rynkowe; technologia; uwarunkowania ekonomiczne; prawo; konkurenci; udziałowcy; grupy nacisku; uwarunkowania społeczne; uwarunkowania polityczne ${ }^{6}$.

Na kryterium kontroli, choć w innym ujęciu, zwracają też uwagę B. Kaczmarek i C. Sikorski, którzy podkreślają, że „im większa zależność organizacji od otoczenia, tym mniejsza z jej strony kontrola nad zasobami w otoczeniu"7.

Odnosząc się do teorii systemów, Marek Pawlak uważa, że „mianem otoczenia określa się wszystkie te elementy, które nie są częściami systemu, ale mają na niego wpływ, względnie te, na które system ma wpływ" ${ }^{8}$. Podejście systemowe uwypukla też Agnieszka Chrisidu-Budnik:

Uznanie organizacji za system i wyodrębnienie jego granic spowodowało konieczność identyfikacji tego, co nie jest systemem. [...] należy stwierdzić, że autorzy prac zajmujących się problematyką relacji organizacja-otoczenie otoczeniem nazywają albo warunki, w jakich funkcjonuje organizacja, albo partnerów, $\mathrm{z}$ jakimi wchodzi organizacja $\mathrm{w}$ interakcje $\mathrm{w}$ toku swojego funkcjonowania ${ }^{9}$.

\section{CECHY I RODZAJE OTOCZENIA}

Biorąc pod uwagę powyższe definicje oraz nie różnicując jeszcze podejścia do otoczenia organizacji na ogólne i szczegółowe, można wskazać kilka cech wspólnych otoczenia każdej organizacji, w tym administracji publicznej. Marek Lisiński zwraca uwagę na cztery właściwości: unikalność, dynamiczną naturę,

5 Z. Martyniak, Rozwój nauki organizacji i zarzadzania. Wybrane zagadnienia metodologiczne, [w:] Organizacja i zarzadzanie. Zarys problematyki, red. A. Stabryła, J. Trzcieniecki, Warszawa 1986, s. 89.

6 D. Waters, Zarzadzanie operacyjne. Towary i ustugi, Warszawa 2001, s. 57 n.

7 B. Kaczmarek, C. Sikorski, op. cit., s. 64.

8 M. Pawlak, Zarzadzanie projektami, Warszawa 2006, s. 13.

9 A. Chrisidu-Budnik, Organizacja i jej otoczenie, [w:] eadem et al., Nauka organizacji i zarządzania, Wrocław 2005, s. 193. 
złożoność i zróżnicowany poziom kontroli otoczenia ${ }^{10}$. Z kolei Jan W. Wiktor, Renata Oczkowska i Agnieszka Żbikowska przytaczają cztery inne cechy ogólne, charakterystyczne ich zdaniem dla otoczenia organizacji: rozległość, zróżnicowanie, niestabilność i kompleksowość ${ }^{11}$. Leszek Korzeniowski wśród najważniejszych atrybutów otoczenia wymienia jego potencjał (hojność otoczenia), różnorodność i niepewność ${ }^{12}$.

Wpływ otoczenia na organizację lub organizacji na otoczenie uzależniony jest od wielu czynników, które determinują przestrzeń wokół organizacji, a także rodzaje otoczenia. Biorąc pod uwagę kryterium podmiotów, których potrzeby realizują organizacje prywatne i publiczne, w pierwszej kolejności należy wymienić otoczenie demograficzne. Dotyczy ono opisu ludności oraz zmian zachodzących w populacji poszczególnych obszarów, na których działa organizacja, w tym jednostki organizacyjne administracji publicznej. Wśród podstawowych mierników demograficznych rozpatruje się głównie: liczbę ludności, wielkość przyrostu naturalnego, strukturę wiekową populacji, wielkość gospodarstw domowych oraz stopień urbanizacji ${ }^{13}$.

Kolejna determinanta odnosi się do określenia otoczenia ekonomicznego, w którym funkcjonuje organizacja. W tym zakresie analizie podlegają takie czynniki, jak: stan gospodarki, dochody indywidualne, poziom rozwoju i szybkość wzrostu gospodarczego, stopień inflacji, wahania kursu walutowego, cykl gospodarczy, sytuacja na rynku pracy ${ }^{14}$.

Z kolei otoczenie społeczne organizacji jest związane ze specyfiką grup społecznych, z którymi „organizacja się styka i które z natury rzeczy mają charakter autonomiczny: nie poddają się dowolnemu oddziaływaniu w procesie zarządzania organizacją" 15 . Jest ono trudno przewidywalne ze względu na cechy zachowań i reakcje ${ }^{16}$ podmiotów, które je budują (odbiorcy, społeczności, pracownicy oraz inni uczestnicy), a wpływ na nie jest związany z ryzykiem i dużą niepewnością oraz wymaga rzadkich umiejętności socjotechnicznych. $Z$ tego powodu niezwykle istotne staje się uzyskanie przez organizację „minimum społecznej akceptacji” dla jej działań ${ }^{17}$.

10 Por. M. Lisiński, Metody planowania strategicznego, Warszawa 2004, s. 36.

11 Por. J.W. Wiktor, R. Oczkowska, A. Żbikowska, Marketing międzynarodowy. Zarys problematyki, Warszawa 2008, https://zieteka.files.wordpress.com/2013/02/wiktor_marketing_miedzynarodowyroz1do3.pdf, s. 42 (dostęp: 28.10.2017).

12 Por. L.F. Korzeniowski, op. cit., s. 401.

13 Por. J.W. Wiktor, R. Oczkowska, A. Żbikowska, op. cit., s. 43.

14 Ibidem, s. 46; Z. Pierścionek, Strategie konkurencji i rozwoju przedsiębiorstwa, Warszawa 2003, s. 93.

15 A.K. Koźmiński, D. Jemielniak, Zarządzanie od podstaw, Warszawa 2011, s. 101.

16 Wśród tych cech należy wymienić przede wszystkim: spontaniczność, emocjonalność i samodzielność podmiotów z otoczenia społecznego. Por. ibidem.

17 Ibidem. 
Spełnienie przez organizację warunku przetrwania (bycia potrzebną) wiąże ją natomiast $\mathrm{z}$ otoczeniem konkretnym ${ }^{18}$, składającym się z tych instytucji, grup i osób, z którymi organizacja musi współpracować, żeby przetrwać i prosperować. Są to elementy otoczenia mające bezpośrednie znaczenie dla organizacji w trakcie realizacji jej codziennych zadań. Otoczenie to często opisuje się w kategoriach interesariuszy — osób, grup i instytucji, na które bezpośredni wpływ mają wyniki działalności organizacji ${ }^{19}$.

Otoczenie konkurencyjne ${ }^{20}$ dotyczy wszystkich powiązań o charakterze konkurencyjnym i kooperacyjnym, jakie zachodzą pomiędzy podmiotami je tworzącymi a organizacją. Charakteryzuje je sprzężenie zwrotne między jego elementami, określane także jako dwubiegunowość istniejących relacji ${ }^{21}$, które jest związane z oddziaływaniem przez podmioty z otoczenia konkurencyjnego na organizację i aktywną reakcją na te bodźce ${ }^{22}$. Ogólnie składniki otoczenia konkurencyjnego określa się jako podmioty gospodarcze, które mają z organizacją różnego rodzaju powiązania ${ }^{23}$, natomiast szczegółowo wymienienia się przede wszystkim takie podmioty i grupy, jak: dostawcy, nabywcy, klienci, odbiorcy dóbr, istniejący i potencjalni konkurenci, producenci dóbr substytucyjnych i komplementarnych, interesariusze wewnętrzni, interesariusze zewnętrzni ${ }^{24}$.

Otoczenie prawne jest istotnym elementem rzeczywistości każdej organizacji i jest związane z regulacjami prawnymi, które wpływają na jej działalność. Wywiera ono wpływ na funkcjonowanie organizacji w różnych aspektach, na przykład: może określać jej osobowość, kształtować zakres terytorialny i przedmiotowy działania ${ }^{25}$, zasady i wartości, które należy respektować. Można stwierdzić,

$18 \mathrm{~W}$ drugiej części tego artykułu jest mowa o otoczeniu konkretnym przedstawionym przez R. Diltsa i Z. Martyniaka. Trzeba uznać za przypadkową zbieżność zastosowanie takiego samego zwrotu na oznaczenie definicji otoczenia przez wspomnianych autorów oraz rodzaju otoczenia ugruntowanego w literaturze przedmiotu. Treść definicji i otoczenia konkretnego jako jego kategorii nie jest tożsama - pierwsza odnosi się do warunków szczegółowych (R. Dilts) lub bardziej ogólnych i usystematyzowanych (Z. Martyniak) otoczenia, natomiast druga kładzie nacisk na interakcje z podmiotami, z którymi organizacja musi współpracować, aby przetrwać.

19 J.R. Schermerhorn, Zarzadzanie. Kluczowe koncepcje, Warszawa 2008, s. 45.

${ }^{20}$ Nazywane jest także otoczeniem sektorowym, otoczeniem branżowym, otoczeniem technologicznym, otoczeniem przemysłowym, otoczeniem bliższym, mikrootoczeniem lub otoczeniem zadaniowym - por. J. Fudaliński, Analizy sektorowe w strategicznym zarzadzaniu przedsiębiorstwem, Kraków 2002, s. 49; K. Kozioł, Analiza otoczenia konkurencyjnego, [w:] K. Janasz et al., Zarzadzanie strategiczne. Koncepcje. Metody. Strategie, Warszawa 2010, s. 171.

${ }^{21}$ J. Fudaliński, op. cit., s. 49.

22 Por. G. Gierszewska, M. Romanowska, Analiza strategiczna przedsiębiorstwa, Warszawa 1994, s. 30-31; J. Fudaliński, op. cit., s. 49.

23 J. Haffer, Skuteczność zarządzania projektami w przedsiębiorstwach działających $w$ Polsce, Torun 2009, s. 47. J. Fudaliński ogranicza te powiązania tylko do konkurencyjnych i kooperacyjnych — por. J. Fudaliński, op. cit., s. 49. Podobnie: G. Gierszewska, M. Romanowska, op. cit., s. 30-31.

24 G. Gierszewska, M. Romanowska, op. cit., s. 30-31; K. Kozioł, op. cit., s. 172.

25 W. Pizło, A. Mazurkiewicz-Pizło, Koncepcja otoczenia organizacji z uwzględnieniem wybranych aspektów międzynarodowych, „Zeszyty Naukowe Szkoły Głównej Gospodarstwa 
że otoczenie prawne dotyczy norm prawnych, „które wyznaczają ramy i warunki funkcjonowania organizacji” ${ }^{26}$. W kontekście otoczenia prawnego ważny staje się również problem stabilności prawa przyczyniający się do mniejszej (lub większej) pewności działania organizacji.

\section{OTOCZENIE ADMINISTRACJI PUBLICZNEJ}

Nie ulega wątpliwości, że unikalność otoczenia organizacji jest cechą wszystkich organizacji, a więc także zorganizowanych podmiotów administracji publicznej. Nie ma dwóch organizacji mających identyczne otoczenie. Oznacza to, że każda organizacja musi dokonywać samodzielnie identyfikacji swojego otoczenia ${ }^{27}$. Jednak w przypadku otoczenia administracji publicznej unikalność ma nieco mniejszy zakres. Uwarunkowane jest to przede wszystkim normami prawnymi, które w odniesieniu do danych rodzajowo jednostek organizacyjnych administracji publicznej narzucają takie same rozwiązania, na przykład: strukturalne, organizacyjne, przedmiotowe, kompetencyjne, form działania, i kategoryzują podmioty, na rzecz których mają one działać. Dlatego w otoczeniu gmin, powiatów, województw, miejskich ośrodków pomocy społecznej, urzędów skarbowych itd. odnaleźć można więcej wspólnych cech niż w otoczeniu organizacji prywatnych.

Zróżnicowany poziom kontroli otoczenia przez organizację powiązany z wpływem organizacji na elementy (czynniki) jej otoczenia w przypadku administracji publicznej determinowany jest głównie przez prawo. Tylko wtedy, kiedy prawo na to zezwala, administracja publiczna może coś robić, oddziałując tym samym na swoje otoczenie. $Z$ tego względu poziom ten będzie się wydawał mniej zróżnicowany niż w przypadku kontroli otoczenia przez podmioty prywatne, ponieważ prawo określa zamknięty katalog sytuacji, w których jest ona dopuszczalna. Jednocześnie to polityka administracji kształtuje otoczenie, w którym działają podmioty prywatne. Takie podejście każe więc zwrócić się w stronę twierdzenia, że zakres kontroli otoczenia sprawowany przez administrację publiczną będzie

Wiejskiego. Ekonomika i Organizacja Gospodarki Żywnościowej” 2008, nr 71, s. 27. Tam również autorzy zwracają uwagę na to, że prawo „określa możliwości działania organizacji, określając normy jakościowe, bezpieczeństwa, wprowadza akcyzę na wybrane produkty, ustala kodeks pracy, narzucając określone zobowiązania organizacjom wobec zatrudnianych przez nie osób. Ogólnie prawo dotyczy ochrony pracowników, konsumentów, środowiska naturalnego, społeczności, narzuca obciążenia finansowe, czasami określa procedury wprowadzania szczególnych produktów, na przykład leków" - ibidem, s. 36.

26 A. Koźmiński, D. Jemielniak, Zarzadzanie od podstaw, Warszawa 2008, s. 108-109. Tam także autorzy zwracają uwagę na to, że owe normy prawne są ,z reguły projektowane jako »twarde« ograniczenia jednoznacznie narzucające określone normy strukturom i procesom realizowanym w organizacji oraz ich efektom (na przykład prawo finansowe, podatkowe, prawo pracy, prawo o spółkach)" - ibidem.

27 Por. M. Lisiński, op. cit., s. 36. 
jednak szerszy niż w przypadku podmiotów prywatnych. Ponadto bardziej widoczne jest sprzężenie zwrotne między kontrolą otoczenia przez administrację publiczną a kontrolą administracji przez otoczenie (społeczności, jednostka). Odmiennie niż w przypadku otoczenia przedsiębiorstwa prywatnego, w przypadku otoczenia administracji publicznej częściej będzie możliwa także kontrola społeczna jej działań.

Określana jako skutek globalizacji, rozległość otoczenia organizacji wyróżnia administrację publiczną w specyficzny sposób. Jest ona zawsze równoznaczna z zakresem właściwości miejscowej jednostki organizacyjnej administracji publicznej wyznaczonej przez prawo. Rozległość otoczenia administracji publicznej w ujęciu ogólnym będzie więc rozumiana jako zasięg jej działania na określonym terenie: lokalnym, regionalnym, państwowym, europejskim, międzynarodowym. W wymiarze ponadnarodowym dominować jednak będą organizacje prywatne, zwłaszcza komercyjne, nastawione na osiągnięcie zysku, a nie na realizację potrzeb publicznych. Rozległość otoczenia w kontekście globalizacji odnosi się głównie do otoczenia organizacji prywatnych, które mogą pozyskiwać zasoby, realizować swoje działania oraz oferować swoje produkty lub usługi w wybranych przez siebie miejscach. W przypadku otoczenia administracji publicznej nie można mówić o samodzielnym wyborze przez nią miejsca i zasobów jej działania. W zakresie rozległości otoczenia, w kontekście globalizacji, można natomiast mówić o powstaniu administracji publicznej europejskiej, unijnej, międzynarodowej, nadal jednak to nie organy administracji publicznej, lecz prawo będzie decydowato o zasięgu jej działania.

Kompleksowość otoczenia organizacji, rozumiana jako zbiór zjawisk zachodzących wokół organizacji, które wzajemnie na siebie wpływają lub są od siebie uzależnione, tworzy sieć powiązań niezbędnych do jej istnienia i sprawnego działania $^{28}$. Administracja publiczna musi tak zarządzać swoim otoczeniem, aby w sposób ciągły mogła realizować zadania na nią nałożone, w tym te, które wynikają z nagłej konieczności, są skutkiem nieprzewidzianego zdarzenia (katastrofa, kataklizm).

Zdolność otoczenia organizacji do stwarzania takich warunków dla organizacji, aby mogła ona trwać i regularnie się rozwijać, jest nazywana potencjałem (hojnością) tego otoczenia. W przypadku otoczenia administracji publicznej wyznaczają go przede wszystkim trzy czynniki: potrzeba społeczna ${ }^{29}$ (zindywidualizowana lub grupowa), chęć jej realizacji za pośrednictwem lub/i z pomocą administracji publicznej oraz zaufanie do administracji publicznej. Dopóki potrzeba

28 Sprawne działanie to takie, które jest skuteczne, ekonomiczne i korzystne. W tym zakresie por. A. Mazurkiewicz, Sprawność działania - interpretacja teoretyczna pojęcia, „Nierówności Społeczne a Wzrost Gospodarczy" 2011, z. 20, s. 47-56.

${ }^{29}$ O znaczeniu potrzeby jako wyznacznika i cechy działalności administracji publicznej por. M. Giełda, Godność człowieka w otoczeniu administracji publicznej, „Przegląd Prawa i Administracji” 111, 2017, s. 43-59. 
będzie generowana przez podmioty z jej otoczenia i będą one chciały korzystać z możliwości jej zaspokojenia, administracja będzie mogła trwać i rozwijać się. Im bardziej podstawowy charakter będzie miała potrzeba, tym większe zapotrzebowanie na jej realizację będzie wykazywało otoczenie, co utwierdzi trwałość i regularność działania administracji publicznej. Podobnie dzieje się, gdy realizacja danej potrzeby jest mało opłacalna, a podmioty prywatne nie są zainteresowane jej realizacją.

W kontekście potencjału otoczenia administracji publicznej bardzo ważne jest zaufanie do niej - im większe, tym lepsze warunki działania administracji publicznej i pewniejsza trwałość jej działania oraz rozwój. W nowoczesnym ujęciu administracja publiczna jest postrzegana jako element sieci łączącej się z otoczeniem. Jej podstawowym elementem powinno być zaufanie warunkowane nie tylko samym faktem sprawnej realizacji zadań, ale też kreatywnym nawiązywaniem współpracy między podmiotami administracji publicznej oraz między nimi a jednostkami organizacyjnymi spoza struktury administracji. Największe nagromadzenie potencjału administracji publicznej w jej otoczeniu dotyczy podmiotów traktowanych indywidualnie jako jednostki (człowiek, osoba). Umiejętne wykorzystanie przez administrację tego potencjału powinno dać skutek w postaci jej sprawnego działania i wzrostu zaufania do niej. Ukierunkowanie na współpracę oraz zwiększenie partycypacji otoczenia w realizacji zadań administracji publicznej jest charakterystyczne dla organizacji sieciowych, przy czym szczególną rolę odgrywa tutaj wiedza menedżerska przedsiębiorstw/organizacji komercyjnych i misja organizacji non profit ${ }^{30}$.

Cecha dynamiczności lub inaczej niestabilności (zmienności) otoczenia administracji jest związana z ciągłą zmianą jego różnych warunków i czynników (postęp technologiczny, zmiana prawa), a jej skutkiem jest niepewność organizacji ${ }^{31}$. To stawia przed administracją publiczną wyzwanie w postaci ciągłego dostosowywania jej działań do zmieniającej się rzeczywistości, łącznie z sytuacjami nagłymi, na które musi reagować szybko i skutecznie. Musi na bieżąco przeprowadzać ciągłą analizę zjawisk zachodzących w jej otoczeniu oraz musi być elastyczna w reagowaniu na zmiany ${ }^{32}$.

Złożoność otoczenia organizacji jest wynikiem ścisłego powiązania oraz interakcji tworzących sieć i zachodzących nieustannie pomiędzy podmiotami, czynnikami i warunkami budującymi jej otoczenie ${ }^{33}$; oznacza ,wzrost liczby jego

30 A. Chrisidu-Budnik, Administracja publiczna w strukturze sieciowej, [w:] Między tradycja a przyszłościq w nauce prawa administracyjnego. Księga jubileuszowa dedykowana Profesorowi Janowi Bociowi, red. J. Supernat, Wrocław 2009, s. 72.

31 Por. L.F. Korzeniowski, op. cit., s. 401.

32 J. Rok, K. Olejniczak, Determinanty uczenia się i zarządzania wiedza - synteza badań empirycznych, [w:] Organizacje uczące się. Model dla administracji publicznej, red. K. Olejniczak, Warszawa 2012, s. 127.

33 Por. M. Lisiński, op. cit., s. 36. 
elementów, które są bardziej zróżnicowane, a ich wpływ coraz trudniejszy do przewidzenia"34. Mimo to od administracji publicznej wymaga się zawsze stabilności w procesie zarządzania jej zróżnicowanym otoczeniem, zwłaszcza jeżeli traktujemy ją jako organizację uczącą się. Złożoność otoczenia jest wymieniana jako jeden $\mathrm{z}$ trzech czynników związanych $\mathrm{z}$ otoczeniem organizacji mającym wpływ na procesy jej uczenia się ${ }^{35}$. Dodatkowo złożoność otoczenia administracji publicznej warunkują także relacje władzy związane $\mathrm{z}$,hierarchicznym i defensywnym charakterem sektora publicznego"36. Skomplikowana struktura i powiązania w ramach administracji publicznej, zakres jej zadań oraz determinacja prawna zadań i organizacji mogą utrudniać przepływ wiedzy i informacji między jej poszczególnymi częściami ${ }^{37}$. Złożoność otoczenia administracji publicznej związana jest także z jego różnorodnością, wzrastającym stopniem wyspecjalizowania organizacji, również w zakresie zaspokajania potrzeb społecznych, nawet bardzo niszowych, oraz liczbą i odmiennością elementów budujących otoczenie.

Otoczenie demograficzne ma podwójne znaczenie dla administracji publicznej: wpływa na strukturę wiekową kadr administracji publicznej oraz determinuje potrzeby jednostek i społeczności, co warunkuje realizację konkretnych zadań przez administrację publiczną. Obecne zmiany demograficzne połączone z nagłymi zmianami technologicznymi i środowiskowymi stawiają przed administracją nowe wyzwania, a „turbulencje i niesprawności rynku nakładają na państwo nowe powinności. Ewoluują jego relacje z obywatelami" ${ }^{38}$. Zmianie ulega nasilenie realizacji różnych kategorii zadań administracji (zwiększenie liczby domów opieki społecznej, pielęgniarek środowiskowych). Srebrna gospodarka (silver econo$m y)^{39}$ wiąże się także z aktywizacją osób starszych — między innymi na rynku

34 A. Sznajder, Strategie marketingowe na rynku międzynarodowym, Warszawa 1995, s. 14.

35 Można wyróżnić trzy czynniki związane z otoczeniem organizacji, które wpływają na jej uczenie się, są to: dostęp do wiedzy, dostęp do zasobów finansowych i złożoność otoczenia. Por. J. Rok, K. Olejniczak, op. cit., s. 126.

36 Ibidem, s. 127.

37 Por. A. Płoszaj, Doświadczenia administracji we Francji, [w:] Zarzadzanie wiedza w organizacjach publicznych: doświadczenia międzynarodowe, red. S. Mazur, A. Płoszaj, Warszawa 2013, s. 52. OECD w swoim raporcie stwierdza wprost, że „skala, zakres i złożoność administracji publicznej utrudniają określenie tego, co jest strategicznie kluczowym elementem powodzenia reformy, a co jest elementem transakcyjnym lub taktycznym, powiązanym z czymś trywialnym lub nieistotnym. Administracyjna złożoność często może zaciemnić pozornie przejrzystą i jasną ścieżkę prowadzącą do reformy" - Polska. Realizacja strategicznych możliwości państwa. Przegląd Zarzadzania Publicznego, OECD 2013, s. 231.

38 S. Mazur, K. Olejniczak, Rola organizacyjnego uczenia się we współczesnym zarządzaniu, [w:] Organizacje uczace się..., s. 26.

39 Silver economy to określenie gospodarki, w której dominującą rolę odgrywają osoby starsze jako konsumenci. Por. M. Lewandowska, Tendencje zmian w makrootoczeniu - perspektywa polskich przedsiębiorstw, „Zeszyty Naukowe. Szkoła Główna Handlowa. Kolegium Gospodarki Światowej” 2010, z. 27, s. 163. Tam również autorka zauważa: „W licznych publikacjach dotyczących tego zjawiska podkreśla się potrzebę większego zaangażowania tej grupy społecznej w two- 
pracy przez stwarzanie odpowiednich warunków, które będą zachęcały do ponownego podjęcia pracy lub do przedłużenia aktywności zawodowej.

Niezwykle ważne dla administracji publicznej jest otoczenie ekonomiczne. To ono niejednokrotnie determinuje treść realizowanych przez nią zadań. Na podstawie analizy otoczenia ekonomicznego administracja publiczna pozyskuje informacje o stopniu konieczności zaspokojenia potrzeb oraz wiedzę na temat rodzaju i zakresu zadań niezbędnych do realizacji i priorytetów. W okresie kryzysu gospodarczego najważniejsze będzie zabezpieczenie realizacji potrzeb podstawowych, wzrasta wtedy zapotrzebowanie na działalność administracji publicznej związaną między innymi z zabezpieczeniem społecznym i aktywizacją bezrobotnych. Kryzys gospodarczy powoduje także zmniejszenie wpływów do budżetu państwa, co skutkuje spadkiem wydatków publicznych na realizację działań administracji publicznej. Inaczej będzie w okresach wzrostu gospodarczego, kiedy wpływy do budżetów publicznych są większe, a potrzeby podstawowe jednostki lub społeczności będą w stanie zapewnić sobie w większości przypadków same. W takim układzie administracja publiczna będzie mogła skupić się na realizacji potrzeb wyższego rzędu (kultura, sztuka).

Społeczne otoczenie administracji publicznej jest jednym z najważniejszych. To na jego rzecz ona działa i ono kreuje potrzeby. Wykluczenie społeczne, prekarność, poczucie braku bezpieczeństwa lub wręcz zagrożenia — to tylko nieliczne współczesne zjawiska powstające w otoczeniu społecznym generujące rozmaite potrzeby indywidualne i zbiorowe, z którymi musi mierzyć się administracja publiczna. Może więc ona być traktowana jako konieczność i wytwór życia w społeczeństwie ${ }^{40}$. Nie jest to jednak związek jednostronny, między administracją publiczną a otoczeniem społecznym występuje ciągłe sprzężenie zwrotne. Administracja publiczna oddziałuje na otoczenie społeczne, a ono w znaczącym stopniu wpływa na działania przez nią podejmowane. Adriana Mazurkiewicz uważa, że „administracja publiczna powstała na skutek potrzeby uporządkowania otoczenia społecznego, a w rezultacie otoczenie to zostało uzależnione od administracji publicznej" ${ }^{41}$. Z tym rodzajem otoczenia administracji publicznej związane jest także zagadnienie zaufania i nastawienia do niej. Należy zwrócić uwagę na jeszcze jeden aspekt, czyli podejście obiektywne podmiotów korzystających z działań administracji publicznej. Ów obiektywizm, ze względu na władczą naturę administracji, jest trudny do zaprezentowania przez adresatów administracji, którzy są zainteresowani głównie partykularnymi interesami, a dopiero potem interesem zbiorowym lub dobrem publicznym. Jest ono więc rzadziej reprezentowane niż

rzenie rozwiązań dotyczących prawodawstwa, a także udoskonalania oferty usług czy towarów dla nich przeznaczonych".

40 A. Mazurkiewicz, Administracja publiczna a otoczenie społeczne, [w:] J. Gierszewski, Administracja publiczna. Skrypt, Chojnice 2012, http://januszgierszewski.pl/wp-content/uploads/2014/06/ Administracja-Publiczna.-Skrypt..pdf, s. 32 (dostęp: 8.01.2018).

41 Ibidem. 
podejście subiektywne, wyrażane przez pozytywne nastawienie do administracji publicznej i związane z tym zaufanie.

W kontekście wspomnianego już prekariatu, dobrze opisanego w nauce ${ }^{42}$, należy zaznaczyć istnienie zjawiska zróżnicowania funkcjonalnego społeczeństw ${ }^{43}$ w otoczeniu administracji publicznej, o którym piszą Stanisław Mazur i Karol Olejniczak, a które odnosi się do struktury tego zjawiska i jednocześnie pokazuje problemy, z jakimi przychodzi mierzyć się administracji publicznej. Ich zdaniem istotą prekariatu jest „tworzenie się w ramach społeczeństwa wielu grup i środowisk mających odrębne tożsamości, różne aspiracje oraz zróżnicowane zasoby"44, a tym samym także różne potrzeby. Skutkiem tego zjawiska jest segmentacja struktur społecznych, a w ich ramach zróżnicowanie interesów i celów, co prowadzi do tworzenia się subsystemów, z którymi administracja publiczna wchodzi w związki w celu wykonywania swojej misji oraz które mają „,zdolność skutecznego wywierania nacisku na procesy decyzyjne zachodzące w sferze publicznej”45.

Powiązane z otoczeniem społecznym i ekonomicznym w sposób bezpośredni i trwały, otoczenie konkretne administracji publicznej jest podobnie jak one związane z potrzebami społecznymi. Jednak w przypadku tej kategorii otoczenia trzeba stwierdzić, że jest ono wręcz uzależnione od nich. Administracja publiczna działa dla ludzi — bez nich i potrzeb, które odczuwają, jej istnienie nie miałoby sensu, byłaby ona niepotrzebna. Spełnianie przez nią oczekiwań społecznych w zakresie realizacji zadań publicznych jest więc tym, co warunkuje jej przetrwanie. Brak zaspokojenia tych oczekiwań natomiast może doprowadzić do sytuacji, w której niektórzy adresaci lub grupy odbiorców działań administracji publicznej przestaną być zainteresowani jej funkcjonowaniem i nie będą realizowali względem niej niezbędnych zasilen' ${ }^{46}$, takich jak podatki, chęć współpracy, partycypacja, zaufanie. Aby wywiązać się ze swoich obowiązków względem społeczeństwa, podmioty organizacyjne administracji publicznej oczywiście muszą współpracować z jednostkami organizacyjnymi, takimi jak dostawcy, podwykonawcy, zawsze jednak będzie to współpraca ukierunkowana na realizację w sposób pośredni lub bezpo-

42 G. Standing, Prekariat: nowa niebezpieczna klasa, Warszawa 2014; R. Szarfenberg, Pęczniejacy prekariat (wywiad), http://www.sprawynauki.edu.pl/index.php?option=com_content\&view $=$ article \&id=2305:prekaryzacja-w-ofensywie\&catid=301\&Itemid=30 (dostęp: 18.12.2019); M. Giełda, Prekarność a ubóstwo, [w:] J. Blicharz, L. Klat-Wertelecka, E. Rutkowska-Tomaszewska, Ubóstwo w Polsce, Wrocław 2014, s. 13-29; A. Patulski, B. Godlewska-Bujok, Prekariat - nastepny etap rozwoju czy raczej przejaw przemocy instytucjonalnej?, „Studia z Zakresu Prawa Pracy i Polityki Społecznej” 2017, nr 2, s. 165-172; G. Krzyminiewska, Prekariat nowym interesariuszem ekonomii społecznej, „Studia i Prace Wydziału Nauk Ekonomicznych i Zarządzania” 2015, nr 41, s. 33-41; K. Cymbrowicz, Prekariat - nowe zjawisko na rynku pracy w Polsce, ,Annales. Ethics in Economic Life" 2015, nr 2, s. 17-30.

43 S. Mazur, K. Olejniczak, op. cit., s. 26.

44 Ibidem.

45 Ibidem.

46 A. Nalepka, Struktura organizacyjna, Kraków 2001, s. 44. 
średni potrzeb społecznych, ponieważ to one uzasadniają konieczność istnienia i trwania administracji publicznej.

Otoczenie konkurencyjne dla prywatnych podmiotów gospodarczych ma większe znaczenie niż dla administracji publicznej, ponieważ jest ona swego rodzaju monopolistą, ma prawnie gwarantowane zadania i kompetencje przynależne tylko i wyłącznie jej oraz ma większe możliwości kreowania rzeczywistości ${ }^{47}$ przez wydawanie między innymi koncesji, zezwoleń lub realizowanie ustalonej polityki zawartej w różnorakich planach. Mimo tak uprzywilejowanej pozycji administracji należy odpowiedzieć na pytanie: $\mathrm{z}$ kim będzie ona konkurować? Jako pierwszą kategorię konkurentów administracji publicznej trzeba wskazać inne jednostki administracji publicznej. Słusznie zauważa Piotr Szreniawski, że już dzisiaj można mówić o istnieniu ,wyboru pomiędzy różnymi organami administracji publicznej, właściwymi do załatwienia konkretnej sprawy"48. Dotyczy to sytuacji, w których ludzie zmieniają miejsce zamieszkania, a tym samym zmieniają się organy administracji publicznej i ich polityka, co w zasadniczym stopniu wpływa na jakość otoczenia ${ }^{49}$. Aspekt konkurencyjności administracji publicznej najlepiej obrazują regiony, gdzie występuje ona w dwóch podstawowych wymiarach. W pierwszym będzie mowa o konkurencyjności wewnętrznej związanej z istnieniem i tworzeniem takich warunków w regionie, które umożliwią potencjalną współpracę pomiędzy administracją publiczną a innymi podmiotami ${ }^{50}$. Konkurowanie bezpośrednie stanowi drugi wymiar i definiowane jest jako „rywalizacja upodmiotowionych jednostek terytorialnych, które konkurują o różnego typu korzyści”" ${ }^{1}$. Najważniejsze jednak jest to, że w przeciwieństwie do podmiotów gospodarczych osiąganie przewagi konkurencyjnej nie może być celem jednostek organizacyjnych działających w strukturze administracji publicznej ${ }^{52}$. Do drugiej

47 Administracja publiczna wpływa na wiele dziedzin życia poprzez na przykład: liczbę działających sklepów sprzedających alkohol, żłobków, przedszkoli, szkół, jednostek oferujących podstawową pomoc medyczną. Ma także wpływ na jakość ich działania i kwalifikacje oraz stopień zaangażowania i empatii pracujących tam osób.

48 P. Szreniawski, Konkurencja $w$ administracji, http://www.szreniawski.strefa.pl/artykulynaukowe/konkurencja.html (dostęp: 10.02.2018).

49 Częstym przypadkiem jest zmiana miejsca zamieszkania (lub tylko zameldowania) przed przystąpieniem do rekrutacji dziecka do żłobka, przedszkola czy szkoły po to, aby skorzystać z usług placówki publicznej, którą rodzice uważają za najlepszą. W zakresie szerszym natomiast P. Szreniawski pisze także o zmianie obywatelstwa, kiedy przedmiotem wyboru jest „zależność od innych władz państwowych i podległość prawu nowego kraju" — ibidem.

50 A. Chrisidu-Budnik, Administracja publiczna w strukturze sieciowej..., s. 75; K. Szymańska, Kierunki zmian kultury organizacyjnej $w$ relacjach urzędu administracji publicznej z otoczeniem, [w:] A. Adamik, M. Matejun, A. Zakrzewska-Bielawska, Problemy i wyzwania w zarzadzaniu organizacjami publicznymi, Łódź 2010, s. 44.

51 A. Chrisidu-Budnik, Administracja publiczna w strukturze sieciowej ..., s. 75.

52 T. Rostkowski, Strategiczne zarzadzanie zasobami ludzkimi $w$ administracji publicznej, Warszawa 2012, s. 99. 
kategorii konkurentów administracji publicznej należeć będą podmioty prywatne (przedsiębiorstwa) oraz sektor non profit.

Prawne otoczenie administracji publicznej to cały szereg regulacji normatywnych różnego rzędu, łącznie z ustawą zasadniczą, które determinują w sposób fundamentalny jej istnienie, zadania i teren działania, a także zasady i wartości, na jakich opiera się jej funkcjonowanie oraz prawa i obowiązki jednostki ${ }^{53}$. Dla Polski, w tym dla administracji publicznej, jednym z najważniejszych faktów, związanych z wpływem otoczenia prawnego, była akcesja Polski do Unii Europejskiej ${ }^{54}$.

Przykładem wpływu otoczenia prawnego na istnienie i działalność administracji publicznej są między innymi samodzielność gmin określona przez szereg ustaw $^{55}$, status prawny pracowników administracji państwowej i samorządowej określony między innymi przez pragmatyki zawodowe, struktura organizacyjna administracji publicznej i podział zadań określony także w ustawach. Również regulacje prawne odnoszące się do podmiotów komercyjnych wywierają bezpośredni lub pośredni wpływ na administrację publiczną.

Faktem jest, że „bez rozsądnego prawa i sprawnego państwa, które będzie je egzekwować, nie powstanie stabilny i efektywny rynek wymiany dóbr i usług, będący z kolei istotnym warunkiem efektywności przedsiębiorstw" 56 prywatnych. Dlatego administracja publiczna (jej działania i polityka administracyjna) także buduje otoczenie prawne i wpływa na podmioty gospodarcze spoza sfery publicznej ${ }^{57}$. Niektóre skutki ich działalności w ramach sprzężenia zwrotnego oddziałują ponownie właśnie na administrację publiczną, na przykład poprzez zasilenie podatkami budżetu państwa lub budżetu samorządowego.

Wśród cech charakterystycznych dla otoczenia prawnego trzeba też zwrócić uwagę na: rosnącą różnorodność przepisów prawnych, coraz powszechniejszą standaryzację oraz rozszerzanie się zakresu przedmiotowego regulacji prawnych. Te cechy są niezmiernie ważne z punktu widzenia funkcjonowania przede wszystkim administracji publicznej i w sposób zasadniczy wpływają na jej działanie zarówno w sposób pozytywny, jak i negatywny.

53 Por. K. Szymańska, op. cit., s. 44.

54 M. Lewandowska, op. cit., s. 164.

55 A.J. Kożuch, Koszty w procesie zarządzania samodzielna jednostka samorzadu terytorialnego, [w:] A. Adamik, M. Matejun, A. Zakrzewska-Bielawska, op. cit., s. 211.

${ }_{56}$ M. Kabut, T. Malesa, Funkcjonowanie przedsiębiorstwa a otoczenie prawne na przyktadzie branży samochodowego transportu tadunków, „Acta Universitatis Nicolai Copernici. Zarządzanie” 2015, nr 3, s. 138.

57 Podkreśla to M. Lewandowska, która zaznacza, że „bardzo ważnym elementem otoczenia administracyjno-prawnego są regulacje administracyjno-prawne, czyli różnego rodzaju formy oddziaływania państwa na wybrane gałęzie gospodarki (poziom mezoekonomiczny), na rodzaje usług, niekiedy na konkretne przedsiębiorstwa (poziom mikroekonomiczny)" - M. Lewandowska, op. cit., s. 165. 


\section{PODSUMOWANIE}

Każda, nawet najmniejsza organizacja funkcjonuje w jakimś otoczeniu. Pomiędzy nią a otoczeniem pojawiają się sprzężenia zwrotne — otoczenie oddziałuje na organizację, a organizacja na otoczenie. Stopień tego oddziaływania może być różny i może dotyczyć różnych dziedzin, ale w przypadku podmiotów administracji publicznej będą to zawsze sprawy, co do których prawo zezwala lub wręcz nakazuje im działać58. Podmioty administracji publicznej mogą przyczyniać się do rozwoju jednostki i społeczności, kreować odpowiednie warunki tego rozwoju poprzez między innymi decyzje administracyjne lub działalność informacyjną, mogą promować wartości i zasady (subsydiarność, ochrona środowiska, społeczna odpowiedzialność organizacji, zrównoważony rozwój), ale mogą także działać destrukcyjnie, na przykład przez brak reakcji administracji tam, gdzie jest ona oczekiwana społecznie, lub podejmowanie błędnej i kosztownej polityki administracyjnej.

Analiza otoczenia administracji publicznej dostarcza jej informacji o tym, czy działa ona skutecznie, a jeśli nie, to co i jak powinna poprawić. Duże znaczenie dla jej działalności mają także zasoby, które znajdują się na terenie jej działania, w tym przede wszystkim zasoby ludzkie. To z nich zwykle podmioty administracji publicznej pozyskują swoich pracowników i to one dostarczają najważniejszych informacji o istniejących na danym terenie potrzebach społecznych.

Administracja publiczna czerpie ze swojego otoczenia, ale też uzależnia je od siebie. Ten związek jest znacznie mocniejszy niż w przypadku organizacji komercyjnych i ich otoczenia. Wynika to przede wszystkim z prawa, ale też z faktu zobowiązania administracji publicznej do realizacji zadań odpowiadających potrzebom społecznym, zwłaszcza jeśli idzie o potrzeby podstawowe, takie jak opieka zdrowotna, edukacja, pomoc społeczna, bezpieczeństwo. Widoczne jest to zwłaszcza podczas okresów recesji gospodarczej, kiedy podmioty prywatne wycofują się z realizacji potrzeb społecznych z różnych powodów (likwidacja przedsiębiorstwa, zawężenie zakresu jego działalności w celu przetrwania, brak opłacalności). To zobowiązanie administracji jest jednocześnie uzasadnieniem jej istnienia i działania.

Zasadnicza determinanta otoczenia administracji publicznej to przede wszystkim prawo (otoczenie prawne), zwłaszcza powszechnie obowiązujące, które określa właściwość terytorialną ${ }^{59}$, zakres zadań, kompetencje, formy działania i orga-

58 Inaczej jest w przypadku podmiotów prywatnych, które mogą realizować wszystkie te działalności, których prawo im nie zakazuje.

${ }^{59} \mathrm{~W}$ przypadku otoczenia administracji publicznej nie można mówić o wyborze przez nią miejsca i zasobów jej działania. O tym decyduje ustawodawca (ustrojodawca), czyli jest ta rozległość determinowana przez prawo i przez prawo jest ograniczona. Administracja publiczna nie może wybrać miejsca swojego działania, tak jak organizacja biznesowa. W zakresie rozległości otoczenia w kontekście globalizacji można natomiast mówić o powstaniu administracji publicznej 
nizację podmiotów administracji publicznej. Wiąże ono administrację publiczną z określonymi podmiotami ${ }^{60}$, dla których została ona stworzona i działa, określa jej status i status podmiotów względem siebie oraz nadaje administracji władcze uprawnienia. Na otoczenie administracji publicznej znaczący wpływ ma także jej przedmiot, ujmowany jako realizacja zadań publicznych wynikających z potrzeb społecznych indywidualnych i zbiorowych. Ten aspekt będzie uzależniony głównie od otoczenia technicznego, ekonomicznego, demograficznego oraz otoczenia konkretnego zorganizowanych podmiotów administracji publicznej.

\title{
THE PUBLIC ADMINISTRATION ENVIRONMENT - SELECTED ISSUES
}

\author{
Summary
}

Between an organisation and its environment, there is always feedback. With regard to public administration it concerns mainly cases in respect of which the law allows or requires it to act. The publication draws attention to the role and relationship of human resources in public administration and its surroundings, it also presents the difference and specificity of the environment of public administration in relation to other organisations and the associated effects. The environment of public administration has also been shown in the context of the contemporary sociological category precariat.

Keywords: organisational environment, public administration, organisation, individual need, group need, law, precariat

\section{BIBLIOGRAFIA}

Chrisidu-Budnik A., Administracja publiczna w strukturze sieciowej, [w:] Między tradycja a przyszłościa w nauce prawa administracyjnego. Księga jubileuszowa dedykowana Profesorowi Janowi Bociowi, red. J. Supernat, Wrocław 2009.

Chrisidu-Budnik A., Organizacja i jej otoczenie, [w:] A. Chrisidu-Budnik et al., Nauka organizacji i zarzadzania, Wrocław 2005.

Cymbrowicz K., Prekariat - nowe zjawisko na rynku pracy w Polsce, „Annales. Ethics in Economic Life" 2015, nr 2.

Dilts R., Od przewodnika do inspiratora, Warszawa 2006.

Fudaliński J., Analizy sektorowe w strategicznym zarządzaniu przedsiębiorstwem, Kraków 2002.

Giełda M., Godność człowieka w otoczeniu administracji publicznej, „Przegląd Prawa i Administracji” 111, 2017.

Giełda M., Prekarność a ubóstwo, [w:] J. Blicharz, L. Klat-Wertelecka, E. Rutkowska-Tomaszewska, Ubóstwo w Polsce, Wrocław 2014.

europejskiej, unijnej, międzynarodowej, nadal jednak to nie administracja publiczna tylko prawo będzie decydowało o jej zasięgu terytorialnym. Inaczej jest w organizacjach prywatnych, które same decydują o swojej rozległości i terenie działania. 
Gierszewska G., Romanowska M., Analiza strategiczna przedsiębiorstwa, Warszawa 1994.

Haffer J., Skuteczność zarządzania projektami w przedsiębiorstwach działających $w$ Polsce, Toruń 2009.

Kabut M., Malesa T., Funkcjonowanie przedsiębiorstwa a otoczenie prawne na przyktadzie branży samochodowego transportu ładunków, „Acta Universitatis Nicolai Copernici. Zarządzanie” 2015, nr 3.

Kaczmarek B., Sikorski C., Podstawy zarzadzania. Zachowania organizacyjne, Łódź 1998.

Korzeniowski L.F., Menedżment. Podstawy zarzadzania, Kraków 2010.

Kozioł K., Analiza otoczenia konkurencyjnego, [w:] K. Janasz et al., Zarzadzanie strategiczne. Koncepcje. Metody. Strategie, Warszawa 2010.

Koźmiński A., Jemielniak D., Zarządzanie od podstaw, Warszawa 2008.

Koźmiński A.K., Jemielniak D., Zarządzanie od podstaw, Warszawa 2011.

Kożuch A.J., Koszty w procesie zarządzania samodzielna jednostka samorządu terytorialnego, [w:] A. Adamik, M. Matejun, A. Zakrzewska-Bielawska, Problemy $i$ wyzwania $w$ zarzadzaniu organizacjami publicznymi, Łodź 2010.

Krzyminiewska G., Prekariat nowym interesariuszem ekonomii społecznej, „Studia i Prace Wydziału Nauk Ekonomicznych i Zarządzania” 2015, nr 41.

Lewandowska M., Tendencje zmian w makrootoczeniu - perspektywa polskich przedsiębiorstw, „Zeszyty Naukowe SGH. Kolegium Gospodarki Światowej” 2010, z. 27.

Lisiński M., Metody planowania strategicznego, Warszawa 2004.

Martyniak Z., Rozwój nauki organizacji i zarządzania. Wybrane zagadnienia metodologiczne, [w:] Organizacja i zarzadzanie. Zarys problematyki, red. A. Stabryła, J. Trzcieniecki, Warszawa 1986.

Mazur S., Olejniczak K., Rola organizacyjnego uczenia się we wspótczesnym zarzq̨dzaniu, [w:] Organizacje uczace się. Model dla administracji publicznej, red. K. Olejniczak, Warszawa 2012.

Mazurkiewicz A., Administracja publiczna a otoczenie społeczne, [w:] J. Gierszewski, Administracja publiczna. Skrypt, Chojnice 2012, http://januszgierszewski.pl/wp-content/uploads/2014/06/Ad ministracja-Publiczna.-Skrypt..pdf (dostęp: 8.01.2018).

Mazurkiewicz A., Sprawność działania — interpretacja teoretyczna pojęcia, „Nierówności Społeczne a Wzrost Gospodarczy" 2011, z. 20.

Nalepka A., Struktura organizacyjna, Kraków 2001.

Patulski A., Godlewska-Bujok B., Prekariat - nastęny etap rozwoju czy raczej przejaw przemocy instytucjonalnej?, „Studia z Zakresu Prawa Pracy i Polityki Społecznej” 2017, nr 2.

Pawlak M., Zarzadzanie projektami, Warszawa 2006.

Pierścionek Z., Strategie konkurencji i rozwoju przedsiębiorstwa, Warszawa 2003.

Pizło W., Mazurkiewicz-Pizło A., Koncepcja otoczenia organizacji z uwzględnieniem wybranych aspektów międzynarodowych, „Zeszyty Naukowe Szkoły Głównej Gospodarstwa Wiejskiego. Ekonomika i Organizacja Gospodarki Żywnościowej” 2008, nr 71.

Płoszaj A., Doświadczenia administracji we Francji, [w:] Zarzadzanie wiedza w organizacjach publicznych: doświadczenia międzynarodowe, red. S. Mazur, A. Płoszaj, Warszawa 2013.

Polska. Realizacja strategicznych możliwości państwa. Przegląd Zarządzania Publicznego, OECD 2013.

Rok J., Olejniczak K., Determinanty uczenia się i zarządzania wiedza — synteza badań empirycznych, [w:] Organizacje uczące się. Model dla administracji publicznej, red. K. Olejniczak, Warszawa 2012.

Rostkowski T., Strategiczne zarzadzanie zasobami ludzkimi w administracji publicznej, Warszawa 2012.

Schermerhorn J.R., Zarządzanie. Kluczowe koncepcje, Warszawa 2008.

Standing G., Prekariat: nowa niebezpieczna klasa, Warszawa 2014.

Przegląd Prawa i Administracji CXX, 2020, cz. 1 i 2

(C) for this edition by CNS 
Szarfenberg R., Pęczniejący prekariat (wywiad), http://www.sprawynauki.edu.pl/index.php?option=com_content\&view $=$ article\&id=2305:prekaryzacja-w-ofensywie\&catid=301\&Itemid=30 (dostęp: 18.12.2017).

Sznajder A., Strategie marketingowe na rynku międzynarodowym, Warszawa 1995.

Szreniawski P., Konkurencja w administracji, http://www.szreniawski.strefa.pl/artykulynaukowe/konkurencja.html (dostęp: 10.02.2018).

Szymańska K., Kierunki zmian kultury organizacyjnej w relacjach urzędu administracji publicznej $z$ otoczeniem, [w:] A. Adamik, M. Matejun, A. Zakrzewska-Bielawska, Problemy i wyzwania w zarządzaniu organizacjami publicznymi, Łódź 2010.

Waters D., Zarzadzanie operacyjne. Towary i ustugi, Warszawa 2001.

Wiktor J.W., Oczkowska R., Żbikowska A., Marketing międzynarodowy. Zarys problematyki, Warszawa 2008, https://zieteka.files.wordpress.com/2013/02/wiktor_marketing_miedzynarodowyroz1do3.pdf (dostęp: 8.01.2018).

Zarządzanie wiedza w systemach informacyjnych, red. B. Łopusiewicz, Wrocław 2004. 